\title{
The role of habitat creation in coral reef conservation: a case study from Aceh, Indonesia
}

\author{
Nur Fadi, Stuart J. Campbell, Kathryn Ferguson, Jude Keyse, Edi Rudi \\ Arthur Riedel and ANDrew H. Baird
}

\begin{abstract}
We describe the successful creation of new reef habitat on Pulau Weh, Indonesia. Coral cover on artificial reef modules increased from a mean of $24 \pm$ SE $2.4 \% 1$ year after the initial attachment of Acropora spp. coral fragments to $64 \pm \mathrm{SE} 4.8 \%$ after 3 years. The artificial reef modules were also rapidly colonized by coral recruits. Recruit densities were $53 \pm \mathrm{SE} 3.2 \mathrm{~m}^{-2}$ on modules that had been submerged for only 1 year, nearly twice as high as recruit densities on natural reef substratum $\left(31 \pm 2.8 \mathrm{~m}^{-2}\right)$. Consequently, the original Acropora assemblage had increased to include at least 23 coral taxa, including 10 additional Acropora species. The artificial reefs also supported at least 29 reef fish species, from 11 families. Unfortunately, this initial success in habitat creation was abruptly halted by a rapid rise in sea temperature in May 2010 that killed almost all corals on the artificial reefs and on nearby natural reefs. Notwithstanding the general view that reef rehabilitation is yet to deliver ecological and conservation benefits at meaningful scales, other benefits of this project included raising the awareness of reef conservation in the local community, promotion of tourism on Pulau Weh and job creation. We conclude, therefore, that habitat creation has a legitimate role as part of an integrated marine conservation strategy.
\end{abstract}

Keywords Aceh, artificial reef, climate change, conservation, coral, Indonesia, Pulau Weh, restoration

\section{Introduction}

Coral reefs support many coastal societies and economies throughout the tropics and have been calculated to generate USD 375 billion annually (Bryant et al., 1998). However, nearly half of the world's coral reefs are considered seriously degraded. According to the Global Coral

Nur FADLI and EDI Rudi Centre for Marine and Fisheries Studies, Syiah Kuala University, Banda Aceh, Aceh, Indonesia

Stuart J. Campbell Wildlife Conservation Society, Bogor, Indonesia

KATHRYN FERguson Centre for Cross-Faculty Inquiry, University of British Columbia, Canada

Jude Keyse and ARthur RIEDEL School of Biological Sciences, University of Queensland, Brisbane, Australia

ANDREW H. BAIRD (Corresponding author) ARC Centre of Excellence for Coral Reef Studies, James Cook University, Townsville, Queensland 4811, Australia. E-mail andrew.baird@jcu.edu.au

Received 19 October 2011. Revision requested 6 December 2011. Accepted 7 February 2012.
Reef Monitoring Network 20\% of reefs have been destroyed and a further $24 \%$ of reefs have lost $50-90 \%$ of their corals (Wilkinson, 2004).

Reef restoration has long been regarded as having an important role to play in addressing the degradation of coral reefs (Precht, 1998). However, based on available case studies, reef restoration has been ecologically ineffective except at very small scales (ICRI, 2005; Edwards \& Gomez, 2007). Some coral species, in particular fast growing, branching taxa such as certain species of Acropora and Pocillopora, can be easily transplanted and survive well (see review by Rinkevich, 2000). Rates of recruitment can be artificially enhanced in degraded areas on a very small scale $\left(<4 \mathrm{~m}^{2}\right.$; Heyward et al., 2002), at least initially (Baria et al., 2010). Also, minimalist interpretations of the shapes of coral can be produced, and put in place to emulate the three dimensional structure of a reef (Jarkeweski \& de Almeida, 2006). However, reef restoration is generally expensive and technically challenging, making it difficult for developing nations to undertake without financial support from international conservation organizations and the technical assistance of foreign experts (ICRI, 2005; Edwards, 2010). For all these reasons, coral reef restoration is now generally recognized as a small scale measure that should be undertaken only when larger-scale causes of damage, such as land-based sources of pollution and sediments, have been addressed (Edwards \& Gomez, 2007).

Some forms of rehabilitation may be justifiable for small areas of high economic value, such as tourist sites (Hughes et al., 2010). However, even at this scale, there are few success stories of reef restoration (Edwards \& Gomez, 2007). Many restoration efforts fail because of poor choice of species, poor site selection, or because the artificial or restored reefs are eventually destroyed by the types of natural disturbance typical of reefs, including cyclones or bleaching (Edwards \& Gomez, 2007). Finally, the success of restoration projects is rarely compared over appropriate spatial or temporal scales with natural rates of recovery, which precludes quantitative evaluations of their performance.

Here, we report on an artificial reef project, initiated and performed by local communities in Aceh, Indonesia. We describe the technique for building the artificial reef, document the changes in the coral and fish assemblage structure over time and compare coral cover and recruit density on the artificial reefs to natural rates of recovery on nearby reefs. We also discuss the importance of habitat creation as part of an integrated marine conservation strategy. 


\section{Methods}

The artificial reef project we describe was initiated by Pak Dodent and the staff of Rubiah Tirta Divers, on Pulau Weh, Aceh, Indonesia (Fig. 1), in response to increased funding for reef rehabilitation following the Indian Ocean tsunami on 26 December 2004. The artificial reefs consisted of concrete modules placed on the seabed of sand and rubble at depths of 2-9 m. Each module was c. $1.25 \mathrm{~m}^{2}$ and there were c. 260 modules in total (Fig. 2). Concrete modules consisted of round blocks with sloping sides and a single section of plastic pipe protruding from the upper surface, contained within four oblong blocks with sloping sides and four sections of pipe for attachment of coral fragments (Plate 1a). A concrete mix was made from three parts aggregate (predominately rubble from buildings damaged by the tsunami, with a particle size of $2-20 \mathrm{~cm}$ ) mixed with one part cement. The concrete mix was then poured into moulds containing coral rubble and rubbish such as empty plastic PET bottles, to reduce the weight, and $\mathrm{c} .70 \mathrm{~cm}$ lengths of $8 \mathrm{~mm}$ iron rebar to strengthen the oblong blocks. The modules were then left on the beach to dry for 1-4 weeks. Divers then manoeuvred the blocks into position by hand on the seabed, where they were allowed to condition. Once oysters had recruited to the blocks, c. 4-6 weeks after immersion, the blocks were scrubbed free of sessile life with a stiff wire brush, to free up space for coral recruitment. Following this treatment, live coral fragments (c. $25 \mathrm{~cm}$ in length) of the staghorn corals Acropora cf. subglabra and Acropora formosa were collected by divers, either from adjacent healthy reefs on Pulau Weh, such as Sea Garden on the eastern side of Rubiah Island (Fig. 1) or, in 2007 and 2008 , from colonies already established on the artificial reef. Fragments were kept in plastic buckets filled with seawater for transportation to the artificial reef site. They were attached to the upright plastic pipes with cable ties (Fig. 2; Plate $1 \mathrm{~b}$ ). The cost of materials for each module was IRD 120,000 and took c. 40 person hours to complete (c. IRD 200,000 per module). Local transport costs were c. IRD 120,000, giving a total cost per module of IRD 440,000 (USD 45). The artificial reef project provided direct employment for three individuals for c. 3 months. Grants totalling at least IRD 80 million (USD 8,500 ) were secured to finance the project (M. Linkie, pers. comm.).

One month following the installation of coral fragments the concrete around the base of the coral fragment was scrubbed again, to reduce competition from recruiting sessile life. Periodic maintenance was carried out, including the righting of toppled blocks, replacement of dead fragments and re-securing of loose fragments. The first trial of the technique occurred in June 2006, a second in August 2007, and a third between December 2008 and January 2009. Consequently, at the time of this study in November 2009

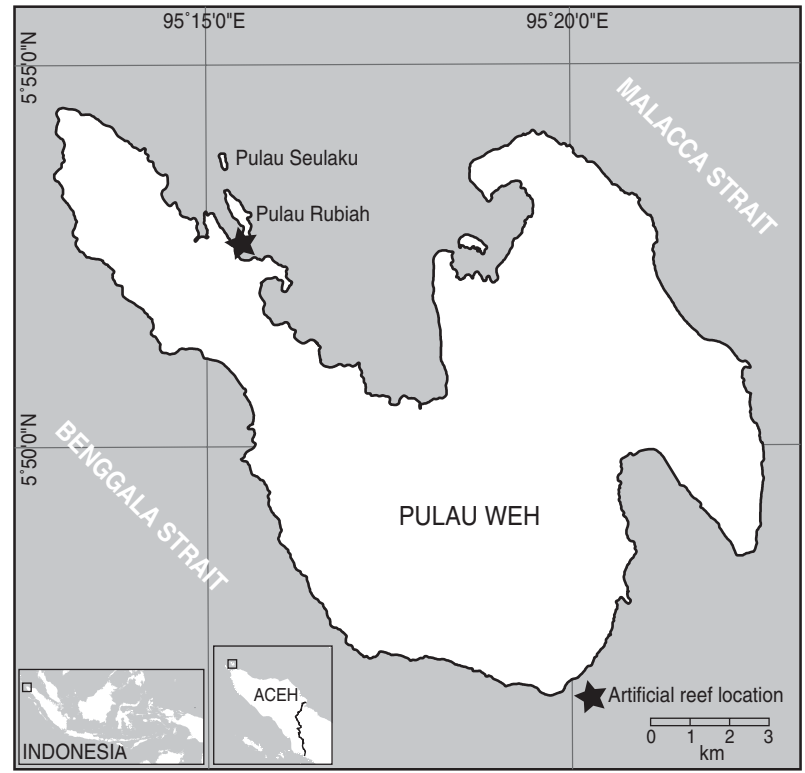

FIG. 1 Pulau Weh, Indonesia, showing the site of the artificial reef project. The insets indicate the location of the main map.

there were artificial reefs of three ages to compare: c. 1, 2 and 3 years old.

To document the development of the artificial reefs, five replicate artificial reef units were selected at random (Fig. 2) and the following response variables quantified: coral cover, coral recruit abundance and diversity, and reef fish abundance and diversity. Coral cover was quantified from digital images of each artificial reef unit. The area of coral cover in each reef unit was estimated from images taken of the artificial reef units, using Image J (Rasband, 1997-2012), and expressed as a percentage of the total horizontal projected area of the reef units. The number and taxa of all visible coral recruits (colonies $<5 \mathrm{~cm}$ maximum diameter) on three randomly selected circular blocks and two randomly selected oblong blocks for each of five separate artificial reef units (Plate 1a) were also tallied underwater by NF, ER and AHB. In addition, the abundance of all reef fish species on each of five replicate reef units of each age was recorded underwater by SJC. Swims along the artificial reefs were undertaken to document additional coral taxa and reef fish species.

To compare the development of the coral assemblage on the artificial reefs to those on natural substratum, coral cover and recruit density were measured on a nearby reef, Teupin Reudeup, which was almost completely denuded of coral when first visited by us in March 2005. Coral cover was estimated with four 10-m line intercept transects and recruit densities were estimated using 25 replicate $1 \mathrm{~m}^{2}$ quadrats. One-way ANOVA was used to test for difference in mean coral cover and recruit density among the four substrata (i.e. 1, 2 and 3 year-old artificial reefs and the natural reef substratum). Raw values of coral cover and recruit density were used after an examination 

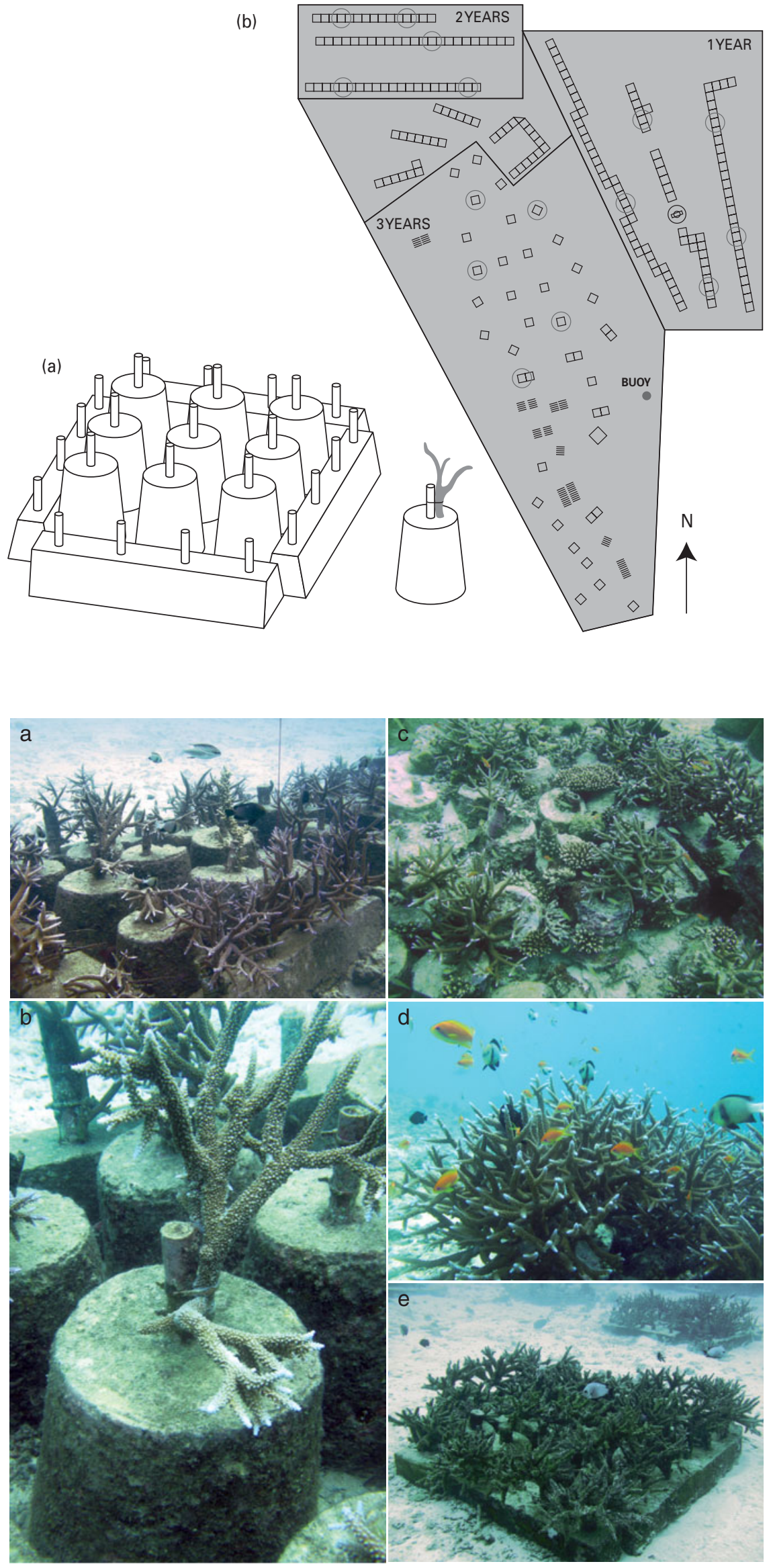

FIG. 2 (a) Schematic diagram of a single artificial reef module, and (b) a map of the layout of the artificial reef showing the spatial arrangement of the modules of different ages and the modules used in this study (circled).
Plate 1 (a) The artificial reef units used as replicates in the study, (b) an Acropora fragment attached to the artificial reef, (c) abundant coral recruits on a 3 year-old artificial reef,

(d) abundant fish life on the artificial reef, and (e) dead coral colonies on an artificial reef module following bleaching in 2010 
of the residuals revealed no major bias in the models. Tukey's HSD tests were used to determine which treatments differed.

\section{Results}

Mean coral cover on 1 year-old artificial reef modules was $24 \pm$ SE $2.4 \%$, significantly lower than that on 2 and 3 yearold modules $\left(F_{(3,15)}=16.6, \mathrm{P}<0.001\right.$; Fig. 3a). Coral cover on the nearby natural reef, Teupin Reudeup, did not differ significantly from that on the 2 and 3 year-old modules but was significantly higher than on the 1 year-old modules (Fig. 3a). Coral cover of $64 \pm$ SE $4.8 \%$ on the 3 year-old structure (Fig. 3a) was almost entirely because of the increase in cover of the original Acropora fragments.

The artificial reefs were quickly colonized by numerous coral recruits (Plate 1c), which averaged $53 \pm \mathrm{SE} 3.2 \mathrm{~m}^{-2}$ on the 1 year-old modules (Fig. 3b). Recruit density did not vary significantly among artificial reef units of different ages (Fig. 3a) but densities on the 1 and 3 year-old modules were significantly higher than on the nearby natural reef $\left(F_{(3,36)}=8.9, \mathrm{P}<0.001\right.$; Fig. $\left.3 \mathrm{~b}\right)$. The diameter of recruits on the older artificial reefs was, however, larger than on 1 year-old reef modules (authors, unpubl. data). Twelve coral
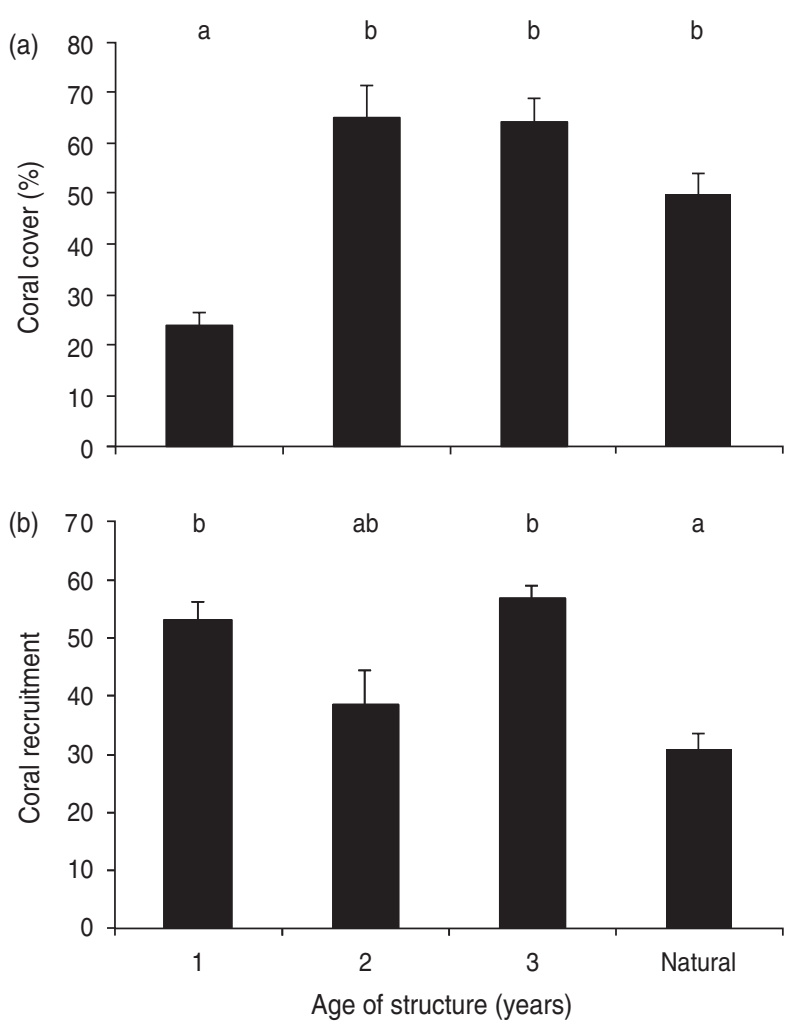

FIG. 3 (a) Percentage coral cover (mean \pm SE) and (b) number of coral recruits (mean number $\pm \mathrm{SE} \mathrm{m}^{-2}$ ) as a function of the age of the artificial reefs (1,2 and 3 years) and on natural substratum. The letters above the bars are the groupings as determined by Tukey's post-hoc tests. taxa were recorded on the 1 year-old modules, increasing to 18 taxa on the 3 year-old modules (Fig. 4a). A total of 23 coral taxa from 8 families were recorded on the artificial reefs, including 10 Acropora species in addition to the two used for fragments (Table 1). These included seven species
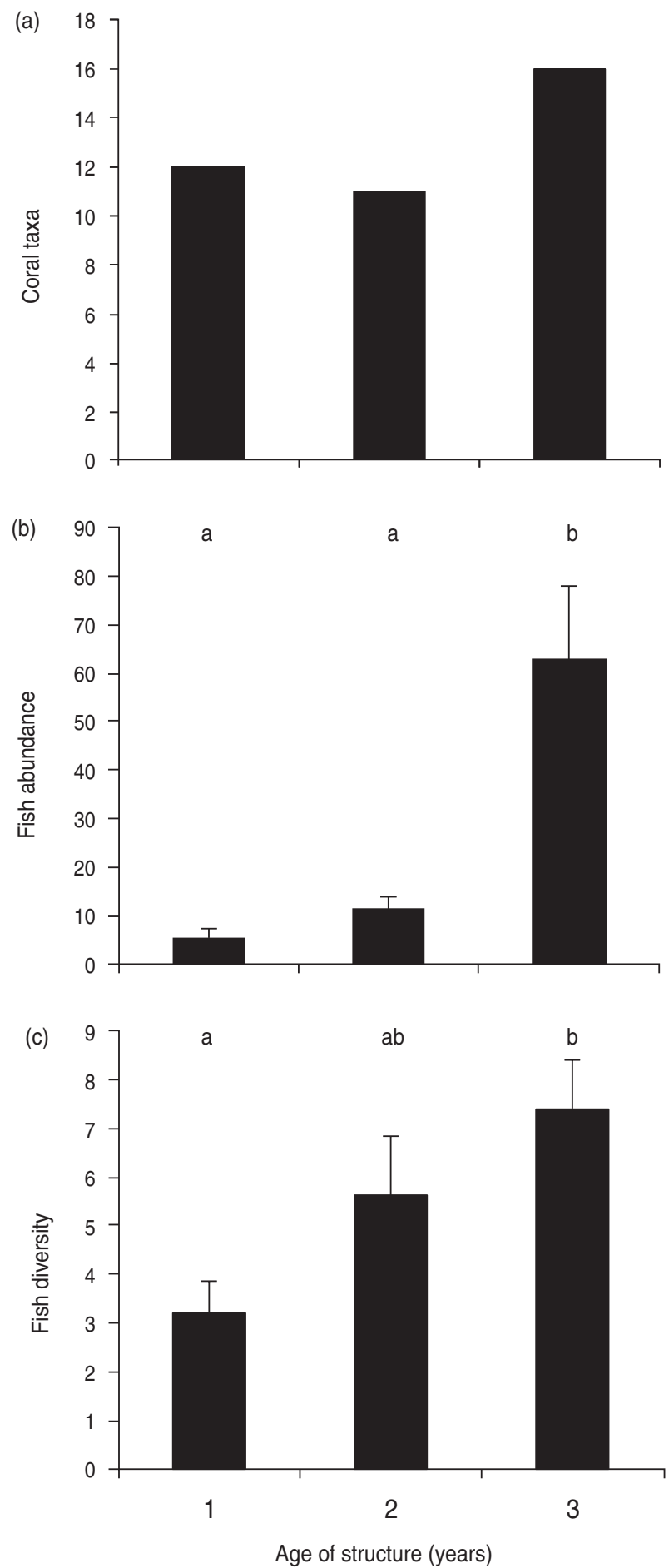

FIG. 4 (a) Number of coral taxa, (b) abundance of reef fish (mean number \pm SE) and (c) change in diversity of reef fish (mean number of taxa \pm SE) as a function of the age of the artificial reefs (1, 2 and 3 years). The letters above the bars are the groupings determined by Tukey's post-hoc tests. 
TABLE 1 Coral taxa recorded on the artificial reefs, by Family, with IUCN Red List Status (IUCN, 2011) for species.

\begin{tabular}{|c|c|c|}
\hline Family & Taxa & $\begin{array}{l}\text { Red List } \\
\text { status* }\end{array}$ \\
\hline \multirow[t]{12}{*}{ Acroporidae } & Acropora anthocercis & $\mathrm{NE}$ \\
\hline & Acropora divaricata & NT \\
\hline & Acropora humilis & NT \\
\hline & Acropora hyacithus & NT \\
\hline & Acropora intermedia & NT \\
\hline & Acropora lutkeni & NT \\
\hline & Acropora muricata & LC \\
\hline & Acropora nasuta & NT \\
\hline & Acropora paniculata & VU \\
\hline & Acropora tenuis & NT \\
\hline & Acropora spp. & \\
\hline & Montipora spp. & \\
\hline Agaricidae & Pavona venosa & VU \\
\hline \multirow[t]{3}{*}{ Favidae } & Cyphastrea sp. & \\
\hline & Favia sp. & \\
\hline & Favites sp. & \\
\hline Poritiidae & Porites sp. & \\
\hline \multirow[t]{3}{*}{ Pocilloporidae } & Pocillopora sp. & \\
\hline & Seriatopora sp. & \\
\hline & Stylophora sp. & \\
\hline Siderastreidae & Psammocora & \\
\hline Astrocoenidae & Stylocoeniella sp. & \\
\hline Milleporidae & Millepora sp. & \\
\hline
\end{tabular}

${ }^{*}$ NE, Not evaluated; NT, Near Threatened; VU, Vulnerable

categorized as Near Threatened and two categorized as Vulnerable on the IUCN Red List (Table 1). The coral recruit assemblage was dominated by the Family Acroporidae ( $45 \%$ of total recruits), Faviidae (23\%) and Pocilloporidae (20\%).

The artificial reefs were also colonized by numerous reef fish (Plate 1d). Reef fish abundance increased exponentially from a mean of $5.4 \pm \mathrm{SE} 1.8$ individuals per 1 year-old module to $63 \pm \mathrm{SE} 15.1$ individuals per 3 year-old module (Fig. 4b). Fish species richness also increased with the age of the artificial reef. A mean of $3.2 \pm$ SE 0.7 species were found on the 1 year-old reef increasing to $7.4 \pm \mathrm{SE} 1.2$ taxa on the 3 year-old reef (Fig. 4C). A total of 29 reef fish species were found in swims across the artificial reefs (Table 2), none of which are listed by the IUCN as threatened, although 16 are either Not Evaluated or Data Deficient (Table 2). Three year-old artificial reefs had developed to the point where they were beginning to attract pelagic predators, such as the carangid Caranx melampygus (Table 2).

\section{Discussion}

The artificial reef project successfully created c. $250 \mathrm{~m}^{2}$ of coral reef habitat that was colonized by a high abundance of coral and fish recruits from many taxa. Coral cover on the artificial reefs was similar to cover on nearby natural reefs and the density of coral recruits was nearly twice as high.
Anecdotal reports suggest an increase in tourism to the area and the project had strong support from local community leaders (Wildlife Conservation Society, unpubl. data). At least IRD 80 million was injected into the local economy and the project directly employed three people.

The probable key to success in rapidly creating habitat was the choice of a coral species (Acropora cf. subglabra) that was resistant to handling, easy to transport, survived well at the chosen depths and grew rapidly. The success of the artificial reefs in attracting coral recruits was most likely the novel method used to prepare the artificial reef substratum but, without controls for this treatment, it is not possible to be certain. Prior to attaching the coral fragments, the cement blocks were conditioned underwater for c. 6 weeks; the precise time was determined by the appearance of oysters on the blocks. The recruitment of oysters suggested that the blocks had been immersed for sufficiently long to allow chemicals that can potentially prevent recruitment of corals to leach from the cement. Cleaning the surface of fouling organisms following this leaching process was also likely to be instrumental in fostering the survival of coral recruits by reducing competitive interactions following recruitment, although peak coral recruitment is likely to occur in April and May following the peak reproductive season of Acropora (Baird et al., 2005), which is a few months before the artificial reef preparations were complete in June 2006 and August 2007. The effectiveness of the artificial reefs in attracting coral reef fishes, once sufficient structure had developed after 2 years, is similar to that of reefs recovering from disturbance, in which there is also a time lag between disturbance and the return of reef fishes (Wilson et al., 2008). The recruitment of fishes to the structures was likely to be from both pelagic larvae and migration from nearby reef areas.

The success of the project is also probably attributable to the health of the marine environment on Pulau Weh. Coral cover and recruitment on the artificial reefs compared favourably to those on natural reef substrata of a similar age. Natural rates of coral growth and recruitment around the island are high. The nearby Teupin Reudeup, for example, was almost totally denuded of coral in March 2005. Cover was $<10 \%$ and there were $<$ five Acropora species present (AHB, pers. obs.). By November 2009 Teupin Reudeup had recovered: coral cover was $50 \pm$ SE $4.2 \%$ and $30 \pm$ SE 2.8 recruits were recorded per $\mathrm{m}^{2}$. The diversity on the artificial reef structures was considerable considering that the total area of the artificial reefs surveyed was $<250 \mathrm{~m}^{2}$ and the fact that the artificial reef began with only two species of Acropora. Diversity was, however, higher on the natural reef, almost certainly because it was larger, with a total area of c. 0.1 ha: 22 species of Acropora were recorded in a 1 hour swim (AHB, unpubl. data) and 82 reef fish species from 18 families were recorded within one $50 \times 5 \mathrm{~m}$ belt transect $(\mathrm{JK}$, unpubl. data). 
TABLE 2 Fish species, by Family, recorded on the artificial reefs, with their IUCN Red List (2011) status.

\begin{tabular}{|c|c|c|c|}
\hline Family & Species & Common name & $\begin{array}{l}\text { Red List } \\
\text { status* }\end{array}$ \\
\hline \multirow[t]{3}{*}{ Acanthuridae } & Acanthurus grammoptilus & Fine-lined surgeon fish & $\mathrm{NE}$ \\
\hline & Acanthurus tristis & Indian mimic surgeon fish & NE \\
\hline & Zebrasoma scopas & Two-tone tang & $\mathrm{NE}$ \\
\hline Blennidae & Meiacanthus smithi & Disco blenny & $\mathrm{NE}$ \\
\hline Carangidae & Caranx melampygus & Bluefin trevally & $\mathrm{NE}$ \\
\hline \multirow[t]{4}{*}{ Chaetodontidae } & Chaetodon falcula & Indian double-saddle butterfly fish & LC \\
\hline & Chaetodon trifasciatus & Pinstriped butterfly fish & $\mathrm{LC}$ \\
\hline & Chaetodon vagabundus & Criss-cross butterfly fish & LC \\
\hline & Chaetodon wiebeli & Hongkong butterfly fish & LC \\
\hline \multirow[t]{4}{*}{ Labridae } & Halichoeres hortulanus & Checkerboard wrasse & LC \\
\hline & Halichoeres scapularis & Brown banded wrasse & $\mathrm{LC}$ \\
\hline & Halichoeres trimaculatus & Three-spot wrasse & $\mathrm{LC}$ \\
\hline & Labroides dimidiatus & Blue-streak cleaner wrasse & LC \\
\hline \multirow[t]{2}{*}{ Labridae-Scarini } & Scarus niger & Dusky parrotfish & LC \\
\hline & Scarus rubroviolaceus & Ember parrotfish & LC \\
\hline Mullidae & Parupeneus macronema & Long-barbel goatfish & $\mathrm{NE}$ \\
\hline \multirow[t]{2}{*}{ Nemipteridae } & Scolopsis aurata & Yellow stripe monocle bream & $\mathrm{NE}$ \\
\hline & Scolopsis bilineata & Two-lined monocle bream & $\mathrm{NE}$ \\
\hline \multirow[t]{2}{*}{ Pomacanthidae } & & Angelfish, unidentified & \\
\hline & Centropyge eibli & Blacktail angelfish & $\mathrm{LC}$ \\
\hline \multirow[t]{4}{*}{ Pomacentridae } & Cheiloprion labiatus & Big-lip damsel & $\mathrm{NE}$ \\
\hline & Chromis weberi & Weber's chromis & $\mathrm{NE}$ \\
\hline & Dascyllus cameus & Indian dascyllus & $\mathrm{NE}$ \\
\hline & Dascyllus trimaculatus & Three-spot dascyllus & $\mathrm{NE}$ \\
\hline Pseudochromidae & Labracinus cyclophthalmus & Fire-tail devil & $\mathrm{NE}$ \\
\hline \multirow[t]{4}{*}{ Serranidae } & Cephalopholis nigripinnis & Blackfin rockcod & $\mathrm{DD}$ \\
\hline & Epinephelus fasciatus & Blacktip grouper & LC \\
\hline & Pseudanthias randalli & Randall's fairy basslet & $\mathrm{NE}$ \\
\hline & Pseudanthias squamipinnis & Sea goldie & $\mathrm{NE}$ \\
\hline
\end{tabular}

${ }^{*}$ DD, Data Deficient; LC, Least Concern; NE, Not Evaluated

The artificial reefs were visited frequently by international dive tourists, who used the site when rough weather prevented trips beyond the channel, and domestic tourists, who snorkelled and fished on the structures. Substantial interest in the artificial reef project was generated following Pak Dodent receiving the Kalpataru award for environmental awareness. This publicity surrounding the award anecdotally increased tourism to the area, particularly among local tourists.

Perhaps the most significant aspect of the project was that success was achieved without the need for expensive foreign advice or technology. Technologies, such as Reef Balls and electrified artificial structures, are highly controversial: there is little evidence they achieve what they claim (Borell et al., 2010) and little support within the research community for their use (ICRI, 2005).

Unfortunately, the artificial reef project came to an untimely end when almost $100 \%$ of the coral colonies were killed following a rapid rise in sea water temperatures in May 2010 (Wildlife Conservation Society, unpubl. data; Plate 1e). Mortality approaching $100 \%$ was also recorded in staghorn Acropora on adjacent natural reefs (AHB, unpubl. data). This event, which affected reefs throughout the Andaman Sea (Krishnan et al., 2011), highlights the challenges faced in conserving local marine ecosystems from threats caused by processes operating on a much larger scale, such as global warming.

This artificial reef project was initiated in response to a large increase in the availability of funding from international donors following the 2004 Indian Ocean tsunami. However, few reefs were directly damaged by the tsunami (Baird et al., 2005; Campbell et al., 2007; Stoddart, 2007) and therefore the ecological justification for the support of reef restoration following the tsunami is questionable (Adger et al., 2005). This artificial reef project demonstrates that there are, nonetheless, good reasons for supporting artificial reef projects; benefits included raising awareness both locally and nationally of coral reef conservation issues, the promotion of community-based tourism, and socioeconomic benefits from an increase in employment for local people. Pak Dodent's artificial reef project provides an alternative and superior model for funding from international donors because it worked and because the economic benefits stayed within the local community. 
Over the past 35 years nearly 200 coral reef restoration projects have been undertaken on coral reefs, at a cost of $>$ USD 200 million, with a combined area of $<_{1} \mathrm{~km}^{2}$ (T.P. Hughes, unpubl. data). Furthermore, many rehabilitation projects fail, like this example on Pulau Weh, because of factors operating on a much larger spatial scale. We conclude that most monies spent on reef restoration should target the causes of reef degradation such as improving land-use practices in reef catchments, and reducing fishing pressure and greenhouse gas emissions. Nonetheless, Pak Dodent's project demonstrates that artificial reefs can play an important role within an integrated marine conservation strategy by raising community awareness of reef conservation and providing economic benefits by increasing employment.

\section{Acknowledgements}

Pak Dodent's artificial reef project was funded by Newmont Mining, AECID, Swiss Contact and many individual donors. The research was supported by an International Collaborative Grant for International Publication Batch II from the Director General of Higher Education, Department of National Education Indonesia (Contract number: 656/SP2H/PP/DP2M/VII/2009, 30 July 2009). The Wildlife Conservation Society was supported by the Kezler Foundation. We thank Fauna \& Flora International and Rubiah Tirta Divers for logistical support while on Pulau Weh. We dedicate this paper to the late Pak Dodent, who worked tirelessly to protect the reefs of Pulau Weh and raise awareness of coral reef conservation in Aceh.

\section{References}

Adger, W.N., Hughes, T.P., Folke, C., Carpenter, S.R. \& Rockstrom, J. (2005) Social-ecological resilience to coastal disasters. Science, 309, 1036-1039.

Baird, A.H., Campbell, S.J., Anggoro, A.W., Ardiwijaya, R.L., Fadil, N., Herdiana, Y. et al. (2005) Acehnese reefs in the wake of the Asian tsunami. Current Biology, 15, 1926-1930.

Baria, M.V.B., Guest, J.R., Edwards, A.J., Alino, P.M., Heyward, A.J. \& Gomez, E.D. (2010) Caging enhances postsettlement survival of juveniles of the scleractinian coral Acropora tenuis. Journal of Experimental Marine Biology and Ecology, 394, 149-153.

Borell, E.M., Romatzki, S.B.C. \& Ferse, S.C.A. (2010) Differential physiological responses of two congeneric scleractinian corals to mineral accretion and an electric field. Coral Reefs, 29, 191-200.

Bryant, D., Burke, L., McManus, J. \& Spalding, M. (1998) Reefs at Risk. A Map-Based Indicator of Threats to the World's Coral Reefs. World Resources Institute, Washington, DC, USA.

Campbell, S.J., Pratchett, M.S., Anggoro, A.W., Ardiwijaya, R.L., Fadli, N., Herdiana, Y. et al. (2007)
Disturbance to coral reefs in Aceh, northern Sumatra: impacts of the Sumatra-Andaman tsunami and pre-tsunami degradation. Atoll Research Bulletin, 544, 55-78.

Edwards, A.J. (ed.) (2010) Reef Rehabilitation Manual. The Coral Reef Targeted Research \& Capacity Building for Management Program, St Lucia, Australia.

Edwards, A.J. \& Gomez, E.D. (2007) Reef Restoration Concepts and Guidelines: Making Sensible Management Choices in the Face of Uncertainty. Coral Reef Targeted Research \& Capacity Building for Management Program, St Lucia, Australia.

Heyward, A.J., Smith, L.D., Rees, M. \& Field, S.N. (2002) Enhancement of coral recruitment by in situ mass culture of coral larvae. Marine Ecology Progress Series, 230, 113-118.

Hughes, T.P., Graham, N.A.J., Jackson, J.B.C., Mumby, P.J. \& STENECK, R.S. (2010) Rising to the challenge of sustaining coral reef resilience. Trends in Ecology \& Evolution, 25, 633-642.

ICRI (International Coral Reef Initiative) (2005) ICRI Resolution on Artificial Coral Reef Restoration and Rehabilitation. Http://www.icriforum.org/sites/default/files/

ICRI_resolution_Restoration.pdf [accessed 14 June 2012].

IUCN (2011) IUCN Red List of Threatened Species v. 2011.2. Http:// www.iucnredlist.org/ [accessed 7 June 2012]

Jardeweski, C.L.F. \& De Almeida, T.C.M. (2006) Fish assemblage on artificial reefs in south Brazilian coast. Journal of Coastal Research, 2, 1210-1214.

Krishnan, P., Roy, S.D., George, G., Srivastava, R.C., Anand, A., Murugesan, S. et al. (2011) Elevated sea surface temperature during May 2010 induces mass bleaching of corals in the Andaman. Current Science, 100, 111-117.

Precht, W.F. (1998) The art and science of reef restoration. Geotimes, $43,16-20$.

RASBAND, W.S. (1997-2012) ImageJ. US National Institutes of Health, Bethesda, USA [http://imagej.nih.gov/ij/, accessed 7 June 2012].

Rinkevich, B. (2000) Steps towards the evaluation of coral reef restoration by using small branch fragments. Marine Biology, 136, $807-812$.

Stoddart, D.R. (2007) The Indian Ocean tsunami special issue. Atoll Research Bulletin, 544, 1-171.

Wilkinson, C. (2004) Status of the Coral Reefs of the World: 2004. Australian Institute of Marine Science, Townsville, Australia.

Wilson, S.K., Fisher, R., Pratchett, M.S., Graham, N.A.J., Dulvy, N.K., Turner, R.A. et al. (2008) Exploitation and habitat degradation as agents of change within coral reef fish communities. Global Change Biology, 14, 2796-2809.

\section{Biographical sketches}

NUR FADLI's research interests include coral reef restoration and management in Indonesia. STUART CAMPBELL's research interests include the effectiveness of marine protected areas in coral reef management. KATHRYN FERGUSON's research focuses on the changing perceptions of coral reefs in space and time. JUDE KEYSE's research explores concordant patterns of marine biodiversity in the Indo-Pacific. ARTHUR Riedel's research explores how evolutionary processes and ecological patterns interact in marine environments. EDI RUDI's research interests include coral reef resilience and the ecology of coral reef fishes. ANDREW BAIRD has broad research interests in coral reef ecology, in particular the evolution of life histories and coral larval ecology. He has been visiting the reefs of Aceh since 1984 . 